\title{
The evolution of saline lake waters: gradual and rapid biogeochemical pathways in the Basotu Lake District, Tanzania*
}

\author{
Peter Kilham ${ }^{1 \dagger}$ \& Paul L. Cloke ${ }^{2}$ \\ ${ }^{1}$ Department of Biology and the Center for Great Lakes and the Aquatic Sciences; ${ }^{2}$ Department of \\ Geological Sciences, The University of Michigan, Ann Arbor, Michigan 48109, USA, Present address: \\ Science Applications International Corporation, Las Vegas, Nevada 89109, USA; (*address \\ correspondence to S. Kilham, Department of Biology, University of Michigan, Ann Arbor, Michigan \\ 48109-1048, USA)
}

Key words: Saline lakes, biogeochemistry, geochemical evolution, sulfate reduction, $\mathrm{CaCO} 3$ precipitation, maars

\begin{abstract}
The biogeochemical evolution of solutes markedly alters the chemistry in the closed-basin maar lakes that comprise the Basotu Lake District (Tanzania, East Africa). Examination of 11 (out of 13) lakes in the Basotu Lake District identified two distinct evolutionary pathways: a gradual path and a rapid path. During the course of biogeochemical evolution these waters follow either the gradual path alone or a combination of the gradual and rapid paths. Solute evolution along the gradual path is determined by all of the biogeochemical processes that for these waters appear to be tightly coupled to evaporative concentration (e.g. mineral precipitation, sorption and ion exchange, $\mathrm{CO}_{2}$ degassing, and sulfate reduction). Rapid evolution occurs when mixing events suddenly permit $\mathrm{H}_{2} \mathrm{~S}$ to be lost to the atmosphere. The chemistry of waters undergoing rapid evolution is changed abruptly because loss of every equivalent of sulfide produces an equivalent permanent alkalinity.

The Basotu Lake District in north central Tanzania is comprised of 13 maar lakes. They range in surface water conductivity from 592 to $24000 \mu \mathrm{S} \mathrm{cm}^{-1}$ (at $20^{\circ}$ ). Within these lake basins only a few of the variety of geo- and biogeochemical processes known to occur in lakes of this type are actually responsible for the gain and/or loss of individual solutes. For example, potassium appears to be taken up in the formation of illite. Calcium is precipitated as calcite. Magnesium interacts with alumino-silicate precursors to form a variety of clay minerals that contain magnesium (e.g. stevensite). This process is also known as reverse weathering. Sulfate is reduced to sulfide and subsequently lost as $\mathrm{H}_{2} \mathrm{~S}$ and/or metal sulfides. Alkalinity is lost owing to calcite precipitation and as a consequence of reverse weathering. Alkalinity is gained in the form of extra permanent alkalinity when sulfide is lost from these waters (via metal sulfide precipitation or gaseous emission to the atmosphere). Rapid (punctuated) evolution can occur in any lake containing anoxic waters providing that mixing events take place which cause $\mathrm{H}_{2} \mathrm{~S}$ to be lost to the atmosphere.
\end{abstract}

\footnotetext{
${ }^{\dagger}$ Peter Kilham died on March 20, 1989, in Kisumu, Kenya, while working as part of a research team on Lake Victoria.
} 


\section{Introduction}

The Basotu Lake District (Tanzania, East Africa) consists of 13 volcanic crater lakes (Fig. 1). The same geochemical mechanisms thought to operate in closed-basin lakes everywhere control, in part, the geochemical evolution of solutes in these lakes. These geo- and biogeochemical processes are: evaporative concentration, cyclic wetting and drying, sorption and ion exchange, 'reverse weathering', mineral precipitation (predominantly carbonates and sulfides in moderately saline African waters), $\mathrm{CO}_{2}$ loss by degassing, and sulfate reduction (Cerling, 1979; Drever, 1988; Eugster \& Jones, 1979; Kilham, 1971a; 1984; Von Damm \& Edmond, 1984).

Recognition of an additional process, however, is required to understand the biogeochemical evolution of waters in the Basotu Lake District, and that is the loss of sulfide from the system. The loss of sulfide from an aquatic system produces permanent alkalinity. Sulfide is lost for the most part to the atmosphere as $\mathrm{H}_{2} \mathrm{~S}$ (and other sulfur containing compounds) or to the sediments when metal sulfides precipitate. Second, physical mixing processes, which contribute to the formation, maintenance, and destruction of thermal and chemical stratification, strongly affect the chemistry of these lakes. Anaerobic bottom waters (hypo- and monimolimnia) develop following stratification. Subsequently, reduction of sulfate to sulfide initiates metal sulfide precipitation. Mixing events, caused by storms, can distribute $\mathrm{H}_{2} \mathrm{~S}$ throughout the mixed layers (epi- or mixolimnia) of a lake from which it is lost to the atmosphere (Maclntyre \& Melack, 1982). When stratification eventually breaks down and turnover occurs, huge quantities of $\mathrm{H}_{2} \mathrm{~S}$ are suddenly lost to the atmosphere (P. Kilham, pers. observ.). Physical mixing processes strongly affect the chemistry of these lakes because one equivalent of permanent alkalinity is produced for every equivalent of sulfide lost.

The geochemical evolution of closed-basin lakes undergoing evaporative concentration is modeled as a gradual continuous process (Garrels \& Mackenzie, 1967; Hardie \& Eugster, 1970).
But, owing to the development and eventual destruction of stratification, the biogeochemical evolution of the Basotu Lakes is at times both rapid and discontinuous.

The chemistry of volcanic crater lakes in East Africa was first studied by Pappe \& Richmond (1890). They analyzed a water sample collected on 17 June 1889 from Lake Katwe, Uganda, by H.M. Stanley's expedition. Stanley (1890) speculates on the origin of the high salt concentrations in Lake Katwe and concludes that evaporation was of primary importance. More recent investigations of the major ion chemistry of volcanic crater lakes in Africa are those of Prosser et al. (1968) in the Bishoftu crater lakes, Ethiopia, and Arad \& Morton (1969) in the Katwe crater lakes, Uganda.

The chemistry of African Lakes is quite well known. Talling \& Talling (1965), Kilham (1971b), and Wood \& Talling (1988) have carried out extensive comparative investigations of the major ion chemistry of African lakes and rivers, while Eugster (1970), Jones et al. (1977), and Eugster \& Maglione (1979) have intensively studied the geochemistry of a few selected lake basins (e.g. Lake Magadi, Kenya, and saline lakes northeast of Lake Chad, Chad).

\section{General description of the Basotu Lake District}

The Basotu volcanic field consists of ca. 30 explosion craters oriented mostly along two parallel NNE-SSW lines about $3 \mathrm{~km}$ apart. The crater lakes studied are shown in Fig. 1. The geology of the craters has been studied in detail by Downie \& Wilkinson (1962). Eades \& Reeve (1938) mapped the geology of the region west and south of Basotu. The craters are punched through the Precambrian Basement which is overlain by Tertiary and Recent deposits.

Figure 2 is a detailed geological section of the wall of Ghama Crater. It shows the stratigraphy of Tertiary and Recent deposits that overlie the Precambrian Basement. During the Miocene, the Basement Complex underwent peneplanation. A layer of quartz conglomerate, apparently depo- 


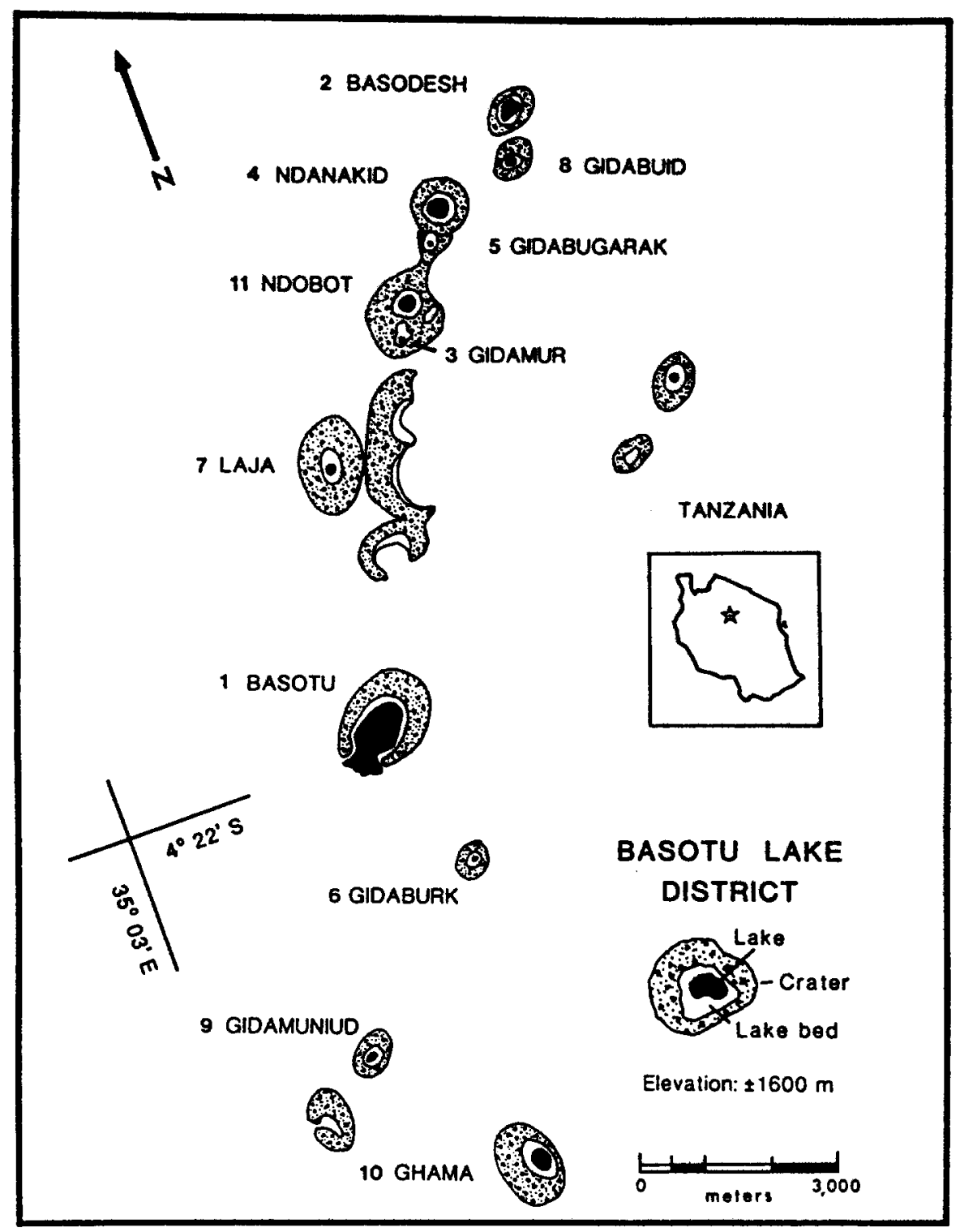

Fig. 1. Map locating explosion craters and maar lakes in the Basotu Volcanic Field. One additional crater, containing Lake Gawali, is ca $6 \mathrm{~km}$ south of Lake Ghama.

sited from fast flowing water, lies immediately above the peneplain. This conglomerate is overlain by $2.5 \mathrm{~m}$ of red clay (illitic), believed to be a flood-plain deposit (Downie \& Wilkinson, 1962). The clay is in turn overlain by ca. $12 \mathrm{~m}$ of poorly bedded buff-colored tuff composed of numerous small crystals (up to $2 \mathrm{~mm}$ ) of aegirine, biotite, quartz, and feldspars in a fine grained matrix of carbonate minerals, quartz, and plagioclase. The 'early tuff' is thought to have originated from Mt. Hanang, a large volcano $23 \mathrm{~km}$ east of Basotu. Capping the 'early tuff' is a layer (ca. $0.5 \mathrm{~m}$ ) of compact fine-grained buff-colored limestone (ca. $75 \%$ calcite).

The cones of the Basotu explosion craters formed above the limestone that caps the 'early tuff and consist of agglomerates and tuffs. The cone-forming pyroclasts range in size from 


\section{GHAMA CRATER}

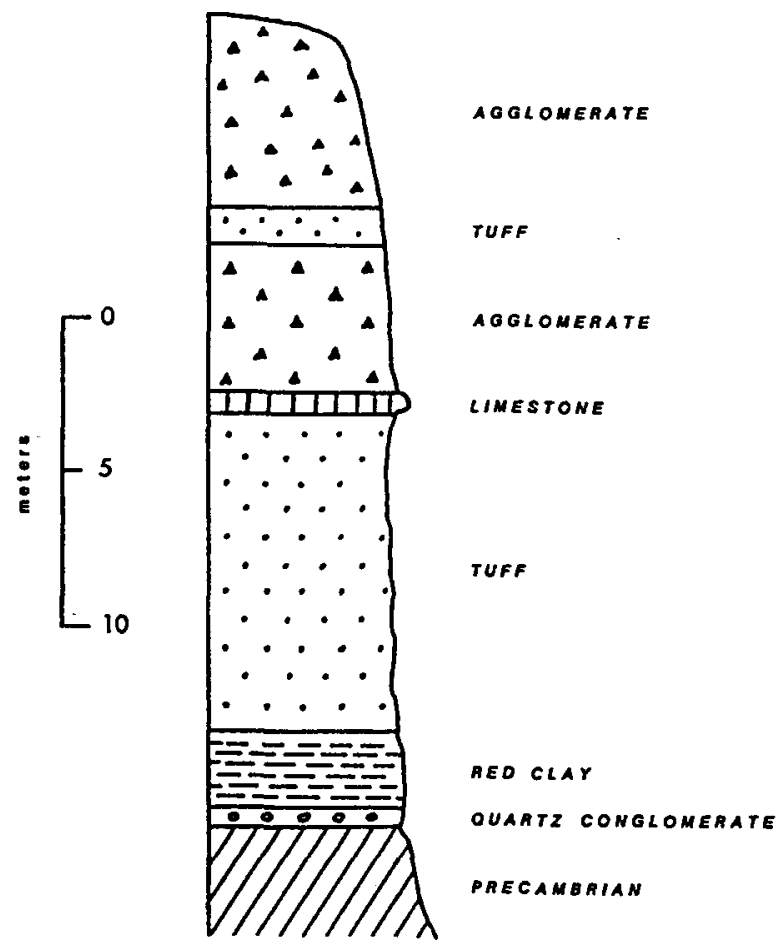

Fig. 2. Detailed geological section (selected for illustrative purposes only) of Ghama Crater (after Downie \& Wilkinson, 1962). The surface of Lake Ghama is about $70 \mathrm{~m}$ below the layer of quartz conglomerate.

micrometers to meters. Their mineralogy is varied. Fragments contain quartz, microcline, plagioclase, perthite, biotite, diopside, augite, aegirine, magnetite, actinolite, garnet, nepheline, etc. Carbonates predominate in the matrix of the tuffs, but fine quartz and plagioclase also occur. Carbonates comprise from $15-45 \%$ of the coneforming rock. Magnesian calcite and a calcitedolomite mixture are the major carbonate minerals present in the matrix. The $\mathrm{MgCO}_{3}$ content varies between $15-38 \%$.

The carbonate rocks at Basotu are considered to have originated as carbonatite (Downie \& Wilkinson, 1962; Dawson, 1964; Heinrich, 1966). Downie \& Wilkinson (1962) propose that owing to local faulting the gas-charged magma exploded violently, causing eruptions, and the fragmentation of the carbonatitic magma gave rise to carbonatitic 'rain'. This 'rain' acted as a matrix for other pyroclasts (Dawson, 1964). Carbonate rocks associated with the 'early tuff' are also considered to be carbonatite; however, these rocks are believed to have been deposited during the explosive eruption of Mt. Hanang. Downie \& Wilkinson (1962) estimate the age of the Basotu explosion craters as Pleistocene.

The climate at Basotu is semi-arid steppe. At Singida (Tanzania; $70 \mathrm{~km}$ southwest of Basotu) the mean rainfall is $663 \pm 167.7 \mathrm{SD} \mathrm{mm} \mathrm{yr}^{-1}$ (Rodhe \& Virji, 1976). It is very dry from June until November, and it rains on and off from November to May. Temperatures in the shade range from $12.8^{\circ} \mathrm{C}$ during the dry season to $32.2{ }^{\circ} \mathrm{C}$ during the wet season.

Many of the Basotu Lakes are believed to be meromictic, but only Lake Gidamuniud was sampled at depth. In Lake Gidamuniud the mixolimnion is only three meters deep $\left(\mathrm{k}_{20}=10800 \mu \mathrm{S} \mathrm{cm}^{-1} ; 20.3^{\circ} \mathrm{C}\right)$. The temperature of the monimolimnion increases more or less linearly from the chemocline to the bottom $\left(\mathrm{k}_{20}=53600 \mu \mathrm{S} \mathrm{cm}^{-1} ; 24.1{ }^{\circ} \mathrm{C}\right.$ at $\left.9 \mathrm{~m}\right)$. Maclntyre \& Melack (1982) studied the formation and destruction of meromixis in a crater lake in Kenya that is generally similar to the lakes at Basotu. They identified basin morphology, the diurnal periodicity of winds and thermal stratification, biological decomposition, and seasonal and yearly changes in rainfall as factors that contribute to the maintenance of meromixis. The surface dimensions of the Basotu Lakes and the maximum depths of their craters are presented in Table 1 .

\section{Material and methods}

Water samples for chemical analysis were collected in $500 \mathrm{ml}$ polyethylene bottles that had been previously soaked in dilute $\mathrm{HCl}$ and repeatedly rinsed with deonized water. Field determinations of $\mathrm{pH}$, calcium, magnesium, chloride, phosphate, silica, and hydrogen sulfide were made with a Portable Water Engineers Laboratory (model DR-EL, Hach Chemical Co.) using 
Table 1. Surface dimensions of the Basotu lakes and the maximum depths of their craters from rim to lake surface (Downie \& Wilkenson, 1962). Based on photographs, craters for which depth data are lacking are probably $>20 \mathrm{~m}$ deep.

\begin{tabular}{lcc}
\hline Lake & $\begin{array}{l}\text { Longest dimension } \\
\text { of each lake } \\
(\mathrm{m})\end{array}$ & $\begin{array}{l}\text { Maximum } \\
\text { depth of crater } \\
(\mathrm{m})\end{array}$ \\
\hline Basotu & 700 & 12 \\
Basodesh & 440 & 18 \\
Gidamur & 100 & - \\
Ndanakid & 380 & 34 \\
Gidabugarak & 68 & - \\
Gidaburk & 100 & - \\
Laja & 180 & - \\
Gidabuid & 98 & 49 \\
Gidamuniud & 140 & 32 \\
Ghama & 290 & 96 \\
Ndobot & 280 & 50 \\
\hline
\end{tabular}

colorimetric and titrimetric techniques. Water samples collected in East and Central Africa between May 1969 and January 1970 were shipped to Duke University for more detailed analysis. Even though agreement between field and laboratory data is good, only laboratory data are presented here unless otherwise noted. The unpreserved samples were analyzed within two years of collection.

Chemical techniques were selected for precision and availability. Sodium, potassium, calcium, magnesium, and silicon were determined by atomic absorption spectrophotometry (PerkinElmer 303: methods described in Perkin-Elmer, 1964). Sodium, potassium, calcium, and magnesium were analyzed in an air-acetylene flame; silicon, and sometimes calcium were done in a nitrous oxide-acetylene flame to preclude the formation of refractory compounds. Standards and aliquots for calcium and magnesium contained lanthanum. On occassion, calcium and magnesium were determined by EDTA titration (APHA, 1965). A Cotlove chloridometer (Lab. Glass and Instr. Co.) was used for concentrations of chloride $>2$ meq $1^{-1}$ and mercuric nitrate titration (APHA, 1965) was used for lower concentrations. Total alkalinity was determined by titration to the bromcresol green-methyl red endpoint
(APHA, 1965). Sulfate was determined turbidimetrically in the field (SulfaVer III, Hach Chemical Co.) and both turbidimetrically (using a precision spectrophotometer) and by ion exchange methods (Mackereth, 1963) in the laboratory. The different methods for calcium, magnesium, and sulfate agreed within $5 \%$ on samples analyzed by two methods. In the laboratory fluoride concentrations (see Kilham \& Hecky, 1973) and pH were estimated electrometrically using appropriate electrodes and buffers. Conductivity was measured in the laboratory on a Philips meter (model PR9501, Philips Electronic Instr. Co.). All chemical analyses were carried out on unfiltered samples. The Basotu lakes were sampled in 1969, lakes Basodesh and Ndanakid were visited on 19 May and the remaining lakes were studied between 21-22 July.

\section{Results and discussion}

Patterns of solute behavior during the geochemical evolution of Basotu lake waters.

Chemical analyses for 11 of the Basotu lakes are given in Table 2. Hecky \& Kilham (1973) and Kilham \& Hecky (1973) published previously some of these analyses as part of their investigations concerning the diatom ecology and fluoride geochemistry in East African waters. This paper represents the first time the geochemistry of these lakes has been studied in detail.

The geochemical evolution of closed-basin lakes undergoing evaporative concentration has been studied in considerable detail. Garrels \& Mackenzie (1967) modeled the isothermal evaporation of Sierra Nevada spring waters. Eugster, Jones, and others have carried out an extensive investigation of Lake Magadi, Kenya (Jones et al., 1977; Eugster \& Jones, 1979). In each of these studies the geochemical evolution of waters within one lake basin was studied. Cerling (1979), on the other hand, showed that chemically similar waters from numerous widely separated lakes in East Africa apparently evolve in a manner not unlike that originally predicted by Garrels \& 


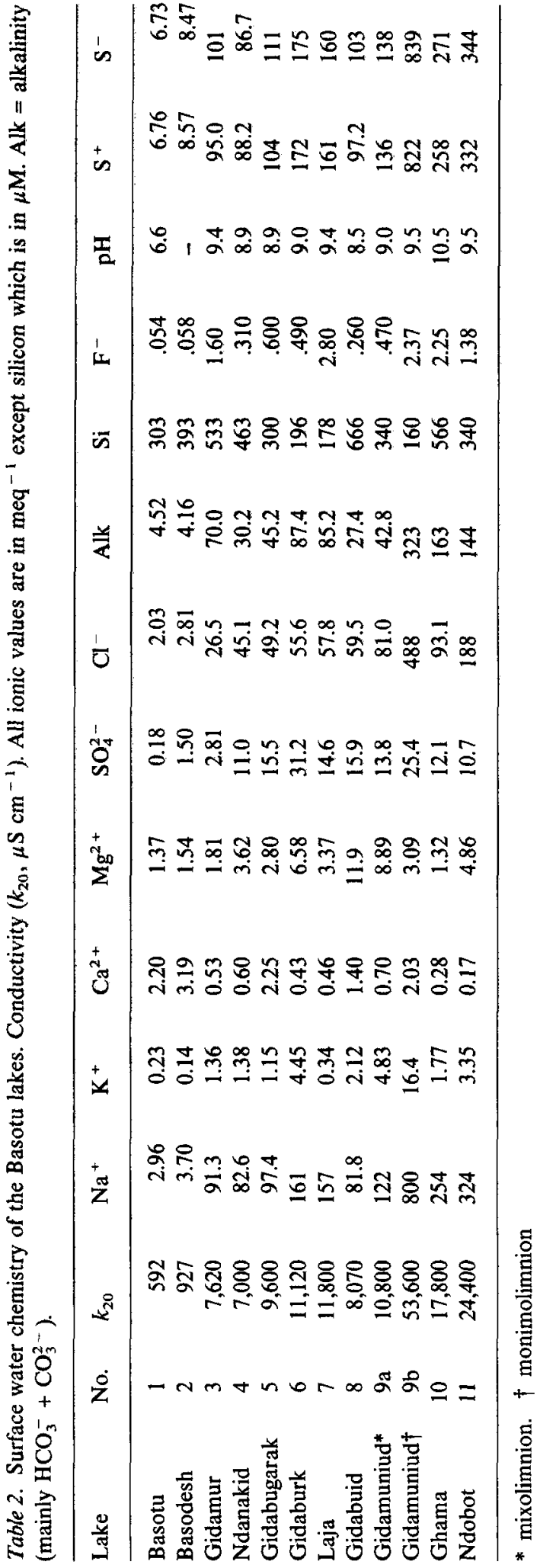

Mackenzie (1967) for a hypothetical lake in the Sierra Nevada.

Because the Basotu lakes share a similar hydrology and climate, we believe we can treat each lake as representing different stages in the geochemical evolution of essentially a single parent water that is characteristic of the lake district, even though some variation in sodium and corresponding concentrations of sulfate and alkalinity seems to occur.

The behavior of major solutes during closedbasin brine evolution has been reviewed by Eugster \& Jones (1979). They propose that individual solutes behave in a variety of ways during the course of evaporative concentration. The five basic patterns identified are shown in Fig. 3. Type I solutes are perfectly conserved species such as sodium and chloride that remain in solution throughout the concentration process. Types II $a$ and $b$ represent solutes (an anion and cation) which combine in the precipitation of a mineral phase. Once saturation is reached, solute $b$ is removed from solution and solute $a$ continues to increase (at a rate less than for a conservative solute). Solutes following this pattern are calcium and carbonate. Type III behavior is shown by bicarbonate and carbonate combined. In this case the solute is gradually removed by a number of processes (e.g. mineral precipi-

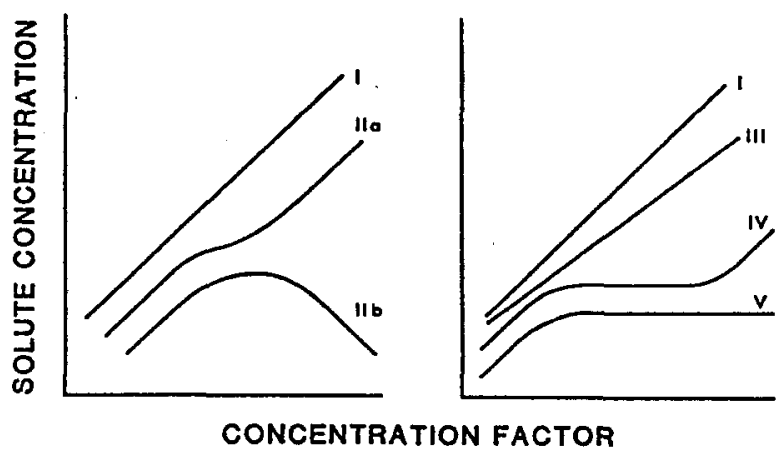

Fig. 3. Diagrammatic representation of the behavior of individual solutes in a solution undergoing evaporative concentration (redrawn from Eugster \& Jones, 1979). Several mechanisms control the behavior of individual solutes. Identifiable patterns of solute behavior are labeled by Roman numerals and discussed in the text. 
tation, sorption, degassing, etc.). The linear relationship which results has a slope less than that found for conservative solutes. Type IV solutes such as potassium and sulfate are removed from solution by mechanisms that Eugster \& Jones (1979) believe are not strongly concentration dependent (e.g. ion exchange, sorption, and biogenic reduction). Because these removal processes act most effectively over the middle of the concentration range a sigmoid curve is produced (Fig. 3). These removal processes are generally thought to take place in the groundwater. Finally, Type $\mathrm{V}$ behavior is shown by solutes such as silicon which remain at relatively constant levels once saturation with respect to the corresponding mineral phase is reached.

We have plotted our data against chloride ion concentrations because chloride is an excellent conservative tracer of evaporative concentration in East African waters (Eugster \& Jones, 1979). Chloride in these waters is thought to be largely derived from rainfall, but few data are available (see Hecky \& Kilham, 1973). Chloride is not known to be removed from solution until halite saturation is reached. When plotted against one another on a log-log plot, conservative solutes concentrated by evaporation fall on a $45^{\circ}$ line (slope $=1.0$ ). The slope of the line is independent of the initial concentrations of the species plotted (Drever, 1988).

Sodium appears to be fairly conservative in the Basotu lakes (Fig. 4A, but see Yuretich \& Cerling, 1983; Von Damm \& Edmond, 1984). The slope of the line for sodium versus chloride is 1.05 and the correlation coefficient $(r)$ is 0.98 (Table 3 ). The sodium to chloride molar ratio varies somewhat (mean $=2.05 \pm 0.71 \mathrm{SD}$ ), but this still probably indicates that all of the lakes evolved from essentially a single parent water.

The behavior of potassium (Fig. 4B) is similar to that of alkalinity (Fig. 6B). The equations for potassium and alkalinity versus chloride (Table 3 ) have similar slopes and correlation coefficients. In contrast to the observations of Eugster \& Jones (1979), potassium in the Basotu lakes is concentrated according to the Type III rather than the Type IV trend. This indicates that potassium is
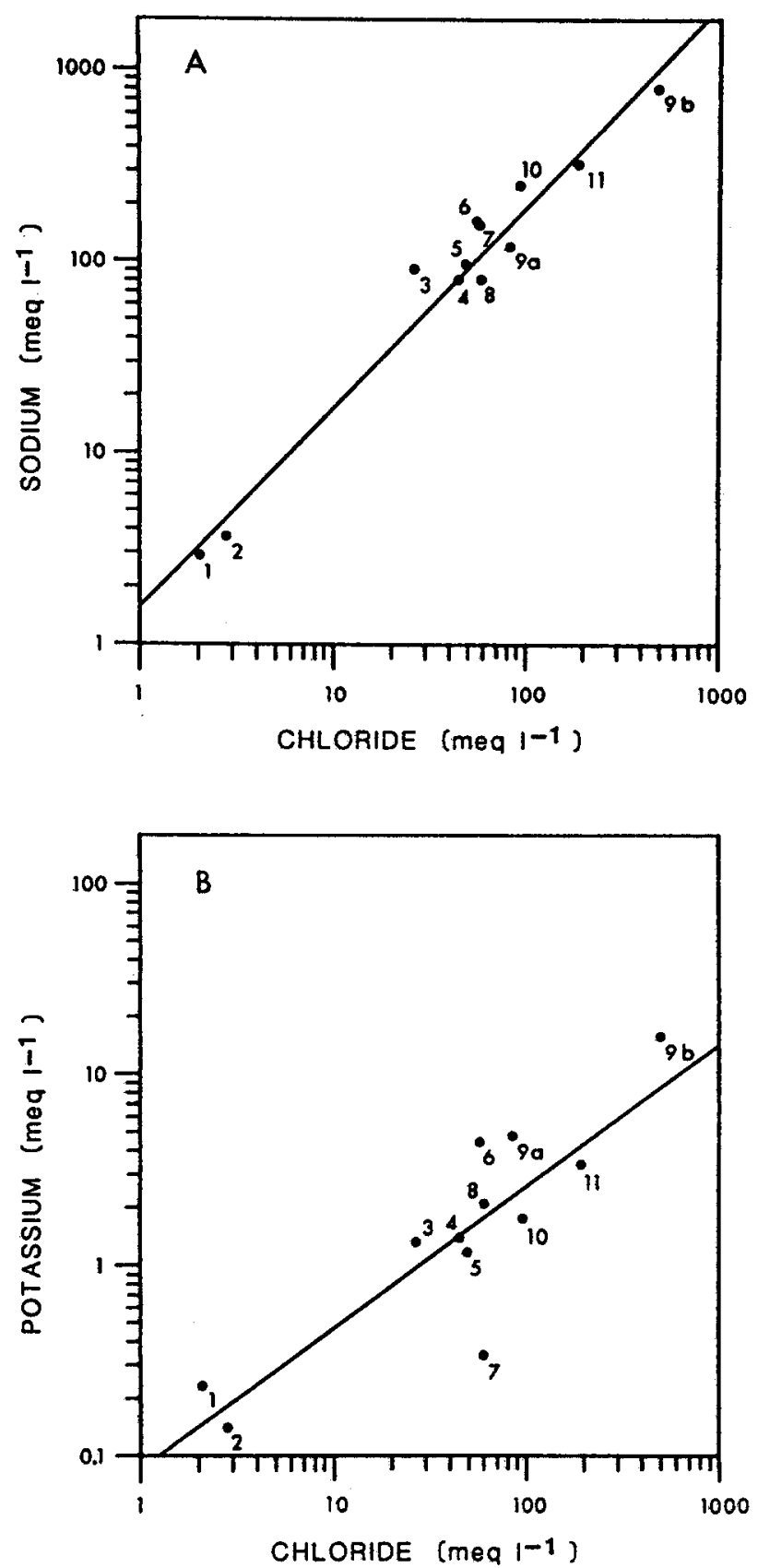

Fig. 4. Plots of sodium (A) and potassium (B) versus chloride for waters of the Basotu Lake District, Tanzania. Equations for regression lines shown are given in Table 3.

possibly being lost from solution within the individual lake basins. Eugster \& Jones (1979) suggest that considerable amounts of potassium are differentially lost from solution over this concen- 
Table 3. Least squares fit equations and correlation coefficients $(r)$ for the major solutes present in the Basotu lakes. All equations were calculated in meq $\mathrm{l}^{-1}$ except silicon which was calculated as $\mathrm{mM}$.

\begin{tabular}{lllr}
\hline Ion & Equation & $r$ & \\
Sodium & $\mathrm{Na}^{+}$ & $=1.63 \times\left(\mathrm{Cl}^{-}\right)^{1.05}$ & 0.98 \\
& & $=0.78 \times(\mathrm{A})^{1.22}$ & 0.97 \\
Potassium & $\mathrm{K}^{+}$ & $=0.08 \times\left(\mathrm{Cl}^{-}\right)^{0.76}$ & 0.86 \\
Calcium & $\mathrm{Ca}^{2+}$ & $=2.43 \times\left(\mathrm{Cl}^{-}\right)^{-0.29}$ & -0.48 \\
& & $=4.10 \times(\mathrm{A})^{-0.42}$ & -0.59 \\
Magnesium & $\mathrm{Mg}^{2+}$ & $=1.41 \times\left(\mathrm{Cl}^{-}\right)^{0.23}$ & 0.48 \\
Sulfate & $\mathrm{SO}_{4}^{2-}$ & $=0.36 \times\left(\mathrm{Cl}^{-}\right)^{0.81}$ & 0.86 \\
& & $=0.30 \times(\mathrm{A})^{0.84}$ & 0.76 \\
Alkalinity & $\mathrm{A}$ & $=2.35 \times\left(\mathrm{Cl}^{-}\right)^{0.79}$ & 0.93 \\
Silicon & $\mathrm{Si}$ & $=0.44 \times\left(\mathrm{Cl}^{-}\right)^{-0.07}$ & -0.23 \\
Fluoride & $\mathrm{F}^{-}$ & $=0.04 \times\left(\mathrm{Cl}^{-}\right)^{0.71}$ & 0.82 \\
\hline
\end{tabular}

tration range, but they consider potassium loss to occur primarily in the groundwater and not in the lakes themselves.

To demonstrate the fractionation between sodium and potassium, and the resulting loss of potassium from solution, Eugster \& Jones (1979) plot the atomic ratio $\mathrm{Na}: \mathrm{K}$ against chloride. For the Basotu Lakes this relationship is $\mathrm{Na}: \mathrm{K}=19$ $(\mathrm{Cl})^{0.29}$. This slope, approximately half that observed for Lake Magadi, strongly resembles the slope (0.24) they determined for a combined plot for three lakes in Oregon (U.S.A., lakes Abert, Summer, and Goose; Eugster \& Jones, 1979). This is not surprising because Jones \& Weir (1983) have shown that clays in the sediments of Lake Abert take up potassium to form authigenic illite. They attribute the slower loss of potassium found in the Oregon basins to either a higher solution to solid surface ratio that decreases the effectiveness of the potassium removal mechanisms and/or to lower rates of chemical weathering, owing to the cooler climate, that may affect the fractionation process. Neither of these explanations can explain that slow loss of potassium in the Basotu Lake District because the climate is semi-arid and similar to that of the Magadi basin.

In the Basotu lakes fractionation between
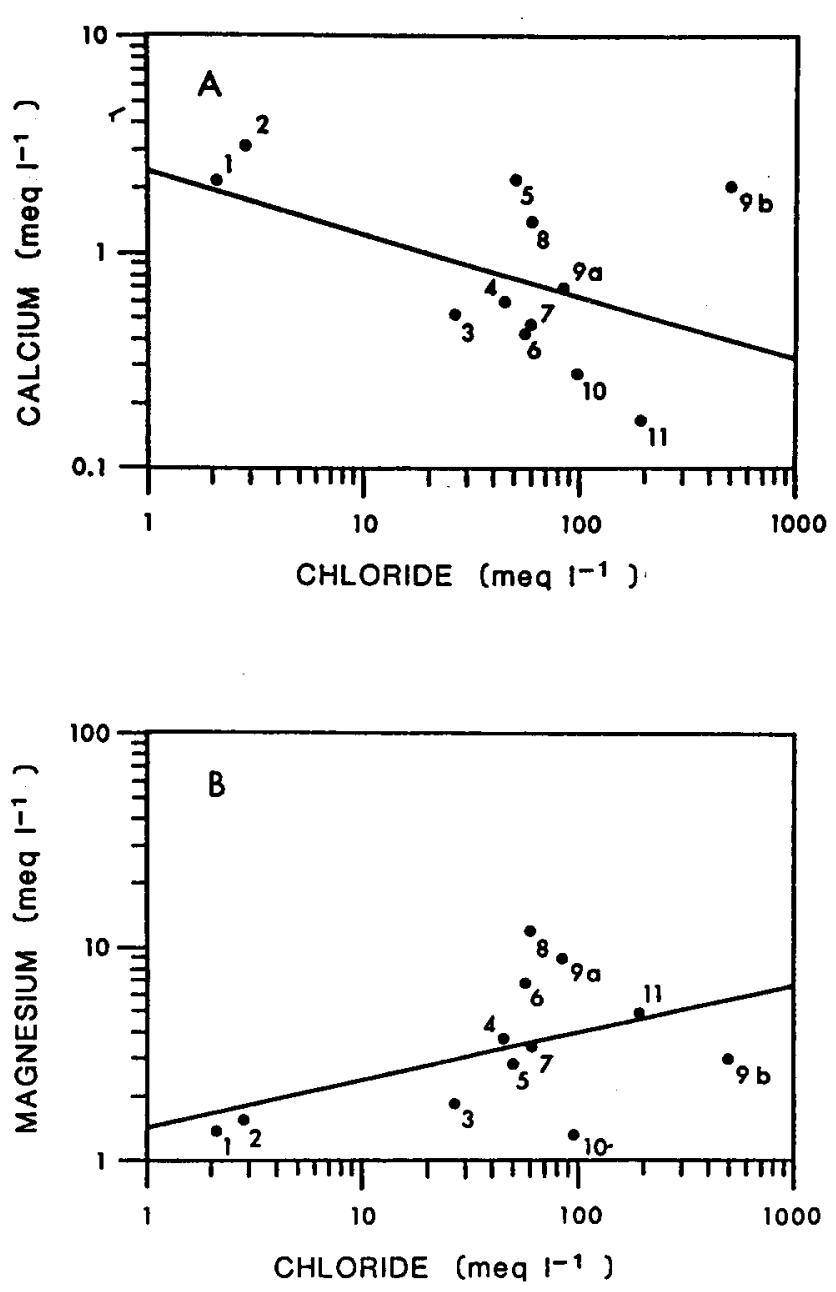

Fig. 5. Plots of calcium (A) and magnesium (B) versus chloride for waters of the Basotu Lake District, Tanzania.

sodium and potassium is possibly rapid in the groundwaters because active surfaces for ion exchange and sorption (i.e. clays and various volcanic rocks) are common in the drainage basins of the lakes. However, considerable evaporative concentration probably occurs in the lakes themselves and clays are a substantial component of the sediments. Abundant illite and lesser quantities of kaolinite and chlorite are present $(P$. Stoffers, pers. comm.). Zeolites also appear. Therefore, abundant ion exchange sites occur in the sediments and these probably cause the gradual loss of potassium from solution. Many authors have suggested that potassium is lost 
from solution in African lakes containing illiterich sediments (Singer \& Stoffers, 1980; Von Damm \& Edmond, 1984; Yuretich \& Cerling, 1983). The potassium : chloride ratio of Lake Laja is exceptionally low (Fig. 4B, No. 7).

Calcium follows Type IIb behavior (Fig. 5A). Although the slope does not look precipitous, over $95 \%$ of the calcium in an initial water like those with the lowest chloride levels would be removed by evaporative concentration and precipitation during evolution to any of the other lake waters. Cerling (1979) also found that considerable amounts of calcium remain in solution in other East African lakes over this concentration range. Figure $5 \mathrm{~A}$ could also be viewed as showing an initial drop in calcium followed by a more or less constant concentration.

Magnesium is at first lost from solution (Fig. 5B), but at chloride concentrations greater than ca. $40 \mathrm{meq}^{-1}$ magnesium begins to behave as a conservative constituent with a more or less constant concentration. According to Eugster \& Jones (1979) the reasons why magnesium behaves as it does are not well understood. Jones \& Weir (1983) found that the enrichment in magnesium of neoformed silicates in Lake Abert (Oregon) increased with increasing salinity. This is compatible with the observations for the Basotu lakes. Particularly high concentrations of magnesium are found in Lakes Gidabuid, Gidamuniud (mixolimnion), and Gidaburk.

The plot of alkalinity versus chloride shows the characteristic Type III pattern (Fig. 6B). Despite the apparent scatter the correlation coefficient is 0.93 (Table 3). Lake Gidamur has a high alkalinity to chloride ratio ( 2.64 by eq) while that of Lake Gidabuid (0.46) is very low.

Our plot of sulfate versus chloride shows the expected amount of scatter (Fig. 6A; Kilham, 1984). In the Basotu lakes sulfate follows the Type III rather than the Type IV pattern. This indicates that considerable amounts of sulfate (in the form of sulfides) are probably being lost in the individual lake basins (see below) rather than from the groundwater. Saturation with respect to gypsum is rarely reached in East African lakes because alkalinity values are high and calcium
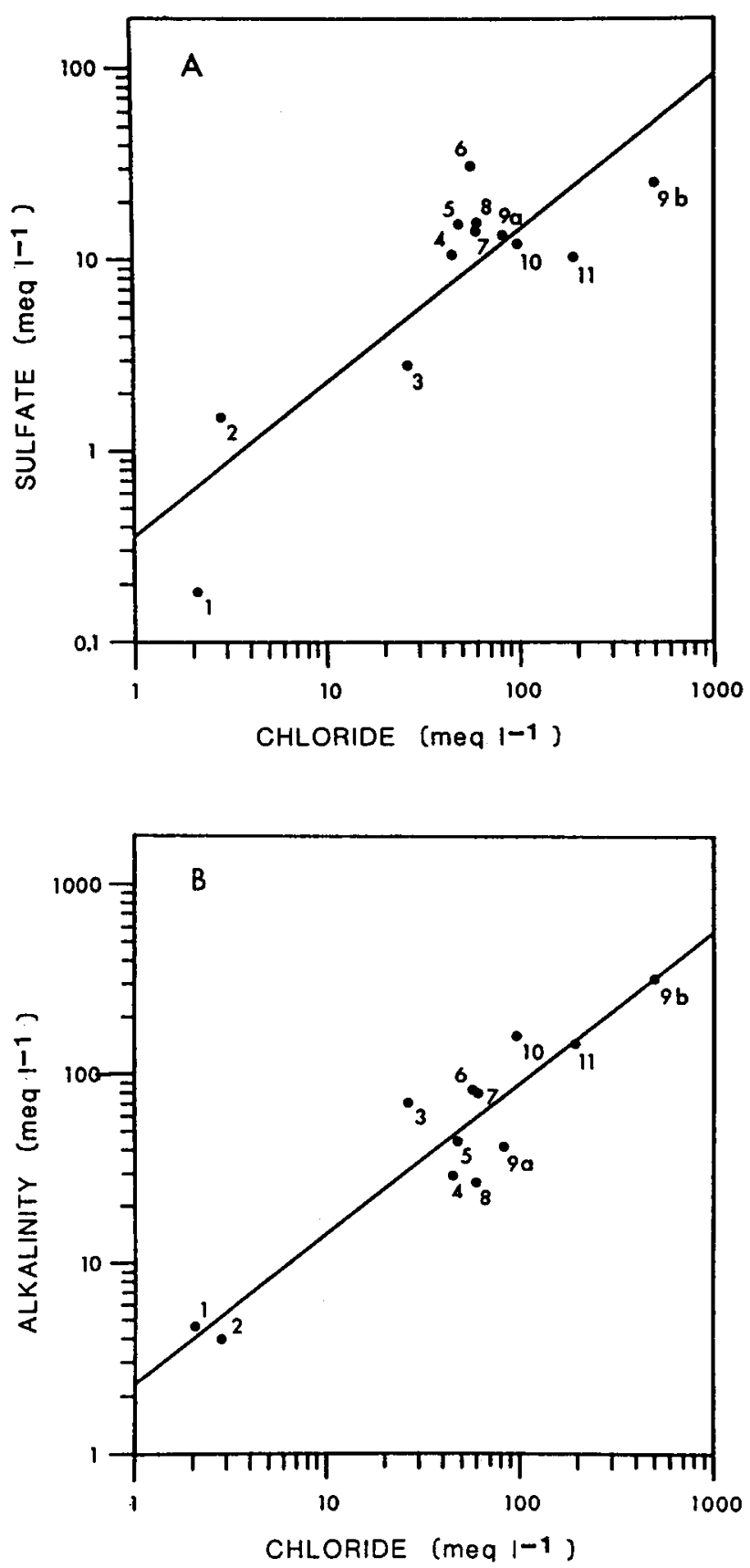

Fig. 6. Plots of sulfate (A) and alkalinity (B) versus chloride for waters of the Basotu Lake District, Tanzania.

values are generally low (Cerling, 1979; Wood \& Talling, 1988).

Silicon concentrations remain relatively constant as chloride concentrations increase over two orders of magnitude (Fig. 7A). Over this range of 

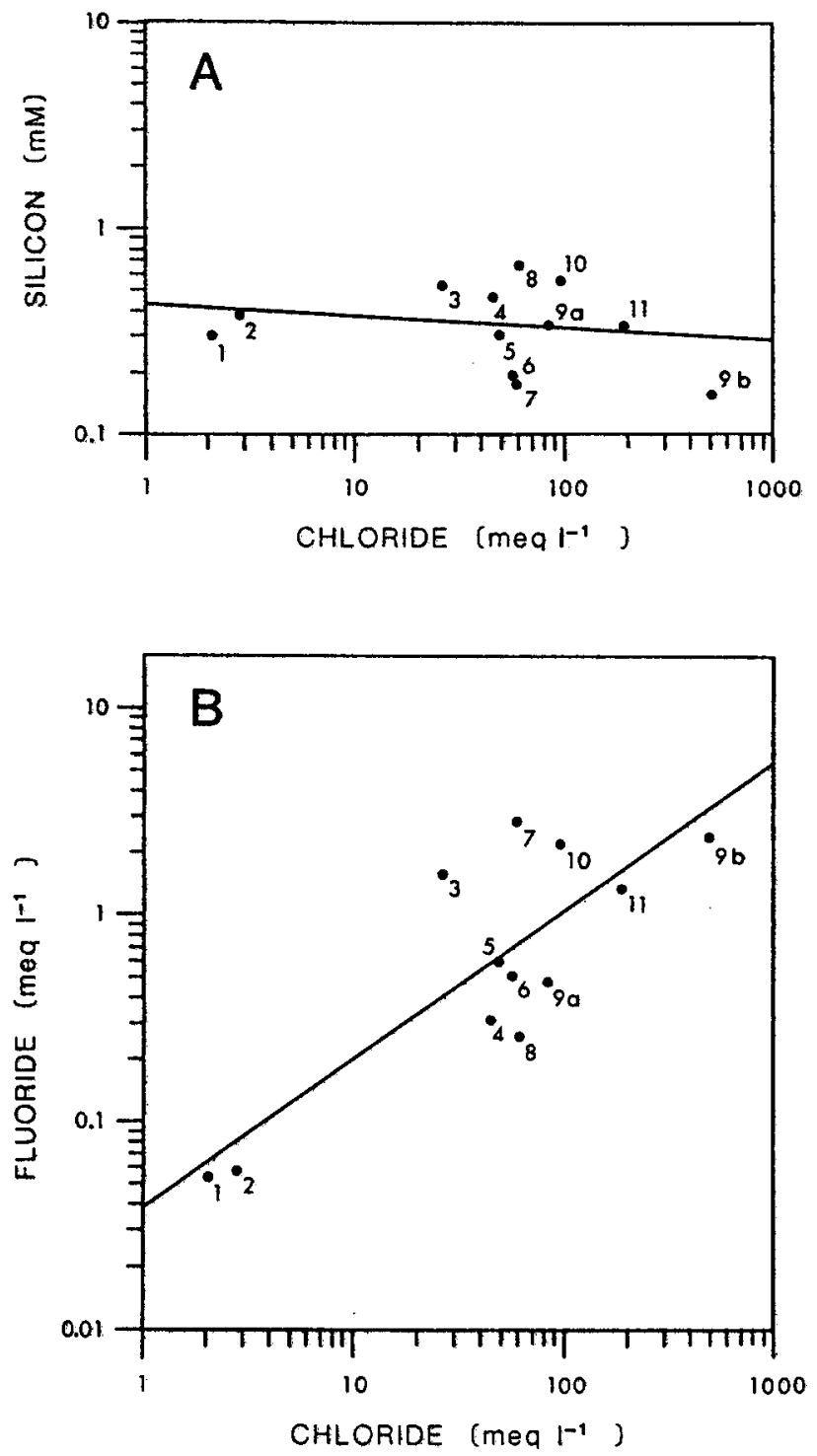

Fig. 7. Plots of silicon (A) and fluoride (B) versus chloride for the waters of the Basotu Lake District, Tanzania.

chloride concentrations, silicon exhibits Type V behavior. All of the lakes contain diatoms and they may be partly responsible for the removal of silicon from solution (Hecky \& Kilham, 1973; Gasse et al., 1983).

The plot of fluoride versus chloride shows considerable scatter (Fig. 7B). The slope of this Type III relationship is only 0.71 . At Lake Magadi, Kenya (Jones et al., 1977) and in the Momela Lakes, Tanzania (Kilham \& Hecky,
1973) fluoride behaves more conservatively than it does at Basotu. Some of the variability in our data may be the result of fluorite or fluorapatite precipitation. Saturation with respect to fluorite occurs in some of the Basotu lakes (calculated using WATEQ; Truesdell \& Jones, 1974) and fluorite has been found in the sediments of other East African lakes (Cerling, 1979). Jones et al. (1977) are equivocal concerning processes removing fluoride in the more dilute waters at Lake Magadi, but they suggest that fluoride-rich waters may interact with minerals such as calcite and gaylussite to produce fluorite in the sediments of concentrated lakes.

Analyses of the Basotu lakes data with respect to the patterns of solute behavior thought to accompany the geochemical evolution of many closed-basin lakes indicate that most of the ions in these waters appear to follow the patterns predicted for a single parent water undergoing evaporative concentration. The major differences observed are for potassium and sulfate which follow the Type III rather than the expected Type IV pattern, presumably because these ions are being removed to a considerable extent in the lake basins themselves. However, there is a great deal of scatter in the plots of all of the ions (except sodium) versus chloride (Figs. 4-6). Much of the observed scatter can be explained geochemically if we examine the evolution of these waters in their individual lake basins.

\section{Evolutionary processes}

The ternary diagram (Fig. 8) shows the proportions of major anions. It also indicates the major pathways these waters may have followed as they evolved. All of these waters are thought to have had an initial anionic composition falling on or near the gradual evolution line, but some (stars in Fig. 8) have undergone rapid evolution and thus now fall below the line. Both evolutionary pathways are discussed below. Even though the Basotu lake waters appear to have originated essentially from a single parent water, the chemical compositions of several indicate that they 


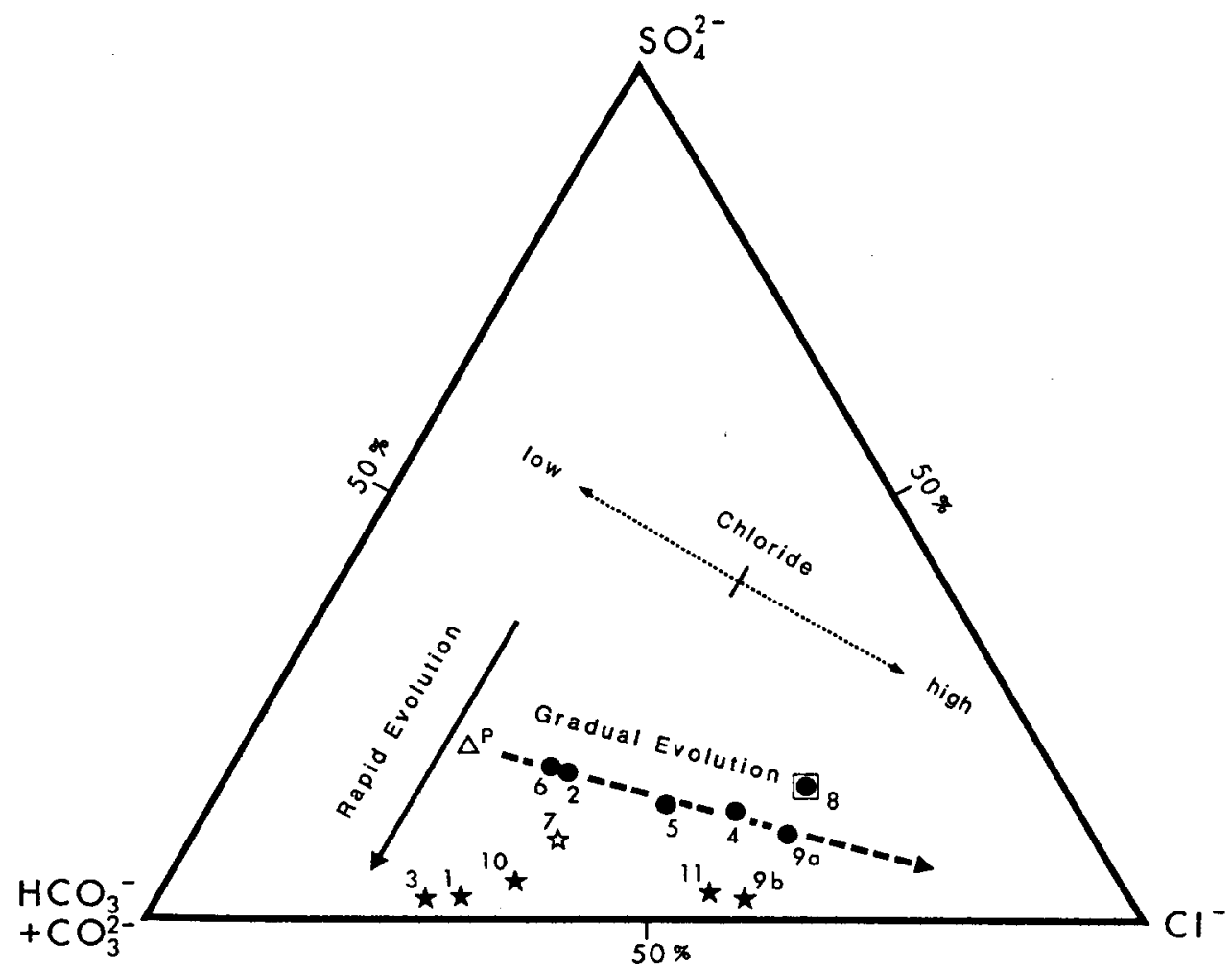

Fig. 8. Ternary diagram showing the proportions of equivalents of major anions for waters in the Basotu Lake District, Tanzania. The circles are high $\mathrm{SO}_{4}$ : Alk ratio lakes and the solid stars are low $\mathrm{SO}_{4}:$ Alk ratio lakes. Lake Laja (open star) is intermediate between the two lake types. Evolutionary trends are indicated by arrows. The open triangle gives a hypothetical anionic composition for the initial parent water (P). Lake Gidabuid (circle in square) is unusual. The lake is very steep-sided and well protected from the wind. It is therefore likely that few sediments are in contact with the mixolimnion. Under such conditions, sulfate reduction is probably reduced in the upper region of the lake.

evolved from waters with higher initial concentrations of sodium (and accompanying concentrations of sulfate and alkalinity) relative to chloride (these are referred to as low chloride waters, see Fig. 8). This indication can be seen in Fig. 4A, where the sodium values for lakes Gidamur, Gidaburk, Laja and Ghama lie appreciably above the regression line, which, as noted above, is essentially conservative. They also lie notably above the regression to a line (which fits the data well, but is not shown) constrained to be strictly conservative in sodium relative to chloride.

The term gradual evolution can be used to describe the geochemical pathway recognized by most previous workers to depict the gradual continuous evolution of alkaline, saline lakes. 'Reverse weathering' or neoformation of clay min- erals is probably an important gradual process in many African lakes, but few quantitative data are available (Carmouze, 1983; Von Damm \& Edmond, 1984; Wood \& Talling, 1988). The following equation, for example, illustrates the formation of chlorite by the reaction of magnesium with kaolinite (presumably or detrital origin):

$$
\begin{aligned}
& \mathrm{Al}_{2} \mathrm{Si}_{2} \mathrm{O}_{5}(\mathrm{OH})_{4}+5 \mathrm{Mg}^{2+}+\mathrm{Si}(\mathrm{OH})_{4}+ \\
& 10 \mathrm{CO}_{3}^{2-}+5 \mathrm{H}_{2} \mathrm{O} \\
& (\text { Kaolinite }) \\
& =\underset{\quad \mathrm{Mg}_{5} \mathrm{Al}_{2} \mathrm{Si}_{3} \mathrm{O}_{10}(\mathrm{OH})_{8}+10 \mathrm{HCO}_{3}^{-}}{\quad(\text { Chlorite })}
\end{aligned}
$$

This equation indicates that 'reverse weathering' results in the loss of base cations, silicate, and alkalinity from solution. Similar reactions could 
be written for formation of magnesium smectites. Some of the variation in the plots of specific ions versus chloride may well be due to this geochemical process.

Rapid evolution occurs when mixing events cause $\mathrm{H}_{2} \mathrm{~S}$ to be suddenly lost to the atmosphere from the surface of a lake. The path of rapid evolution shown in Fig. 8 (solid arrow) is defined by (in eq)

$\left(\mathrm{SO}_{4}^{2-}\right)_{\text {initial }}-\left(\mathrm{SO}_{4}^{2-}\right)_{\text {final }}=\left(\mathrm{OH}^{-}\right)_{\mathrm{EPA}}$

where EPA stands for extra permanent alkalinity. In other words, one equivalent of EPA is produced per equivalent of sulfate (in reduced form) stored or lost from the system. Sulfate reduction by anaerobic bacteria is described by

$\mathrm{SO}_{4}^{2-}+2 \mathrm{CH}_{2} \mathrm{O} \rightarrow \Sigma \mathrm{H}_{2} \mathrm{~S}+2 \mathrm{HCO}_{3}^{-}$

where $\mathrm{SO}_{4}^{2-}$ is balanced by metal cations or hydrogen and $\mathrm{CH}_{2} \mathrm{O}$ is organic matter (Berner, 1971). Even though this reaction is generally the primary source of $\mathrm{H}_{2} \mathrm{~S}$, some $\mathrm{H}_{2} \mathrm{~S}$ results from putrefaction (Dunnette et al., 1985). EPA is formed when $\mathrm{H}_{2} \mathrm{~S}$ is lost to the atmosphere and when metal sulfides precipitate (see Goldhaber \& Kaplan, 1974 for representative reaction; Kilham, 1984). Sulfate reduction, net-sulfate (or sulfide) loss, and the formation of EPA occur in all the Basotu lakes, but these processes are closely associated with evaporative concentration in the lakes falling on or above the gradual evolution line in Fig. 8. Mixing events resulting in sudden loss of $\mathrm{H}_{2} \mathrm{~S}$ (rapid evolution) rather than the evaporative concentration process per se have significantly influenced the geochemical evolution of waters falling below the gradual evolution line.

Even though rapid evolution is defined as occurring whenever $\mathrm{H}_{2} \mathrm{~S}$ is lost rapidly from a lake, the current chemical compositions of the Basotu lakes that have undergone rapid evolution are thought to be the result of numerous mixing events that have taken place over thousands of years.

\section{Sulfate versus alkalinity}

The graph sulfate versus alkalinity for the Basotu lakes (Fig. 9) indicates that these waters, with one exception, plot along two distinct regression lines. The upper regression line was calculated for lakes Basodesh, Ndanakid, Gidabuid, Gidabugarak, Gidamuniud (mixolimnion), and Gidaburk. Lakes with high sulfate to alkalinity ratios (in eq) will be called 'high ratio lakes'. Lake Basotu, Gidamur, Gidamuniud (monimolimnion), Ghama, and Ndobot are 'low ratio lakes' that fall on the lower regression line. Lake Laja plots in an intermediate position and was not included in either regression. The solid central line in Fig. 9 is the regression for all the points shown.

For the low ratio lakes affected by rapid evolution, final alkalinity values appear to be determined by the same geochemical processes that determine bicarbonate and carbonate alkalinity at

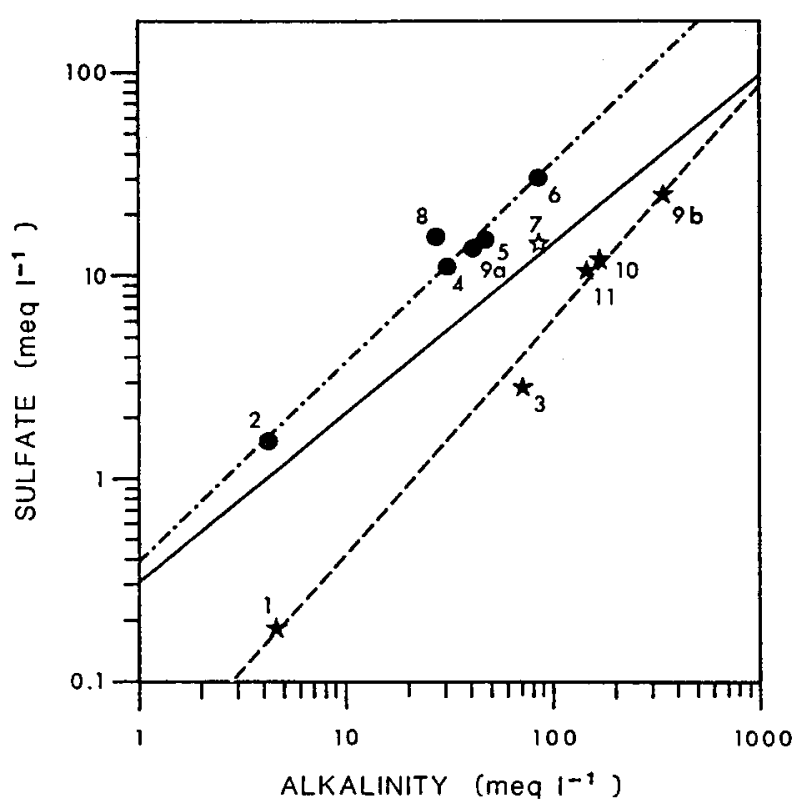

Fig. 9. Plot of sulfate versus alkalinity (Alk) for the Basotu lakes, Tanzania. The solid regression line includes all points (see Table 3$)$. The upper regression line $\left(\left(\mathrm{SO}_{4}\right)=0.41\right.$ $\left.(\mathrm{Alk})^{0.98}, r=0.98\right)$ encompasses the high ratio waters (circles). The lower regression line $\left(\left(\mathrm{SO}_{4}\right)=0.03(\mathrm{Alk})^{1.17}\right.$, $r=0.99$ ) encompasses the low ratio waters (solid stars). Lake Laja (open star) was not included in either regression (see text). 
any given stage of evaporative concentration. Chloride enrichment (an increase in the molar ratio

$\left(\mathrm{Cl}^{-}\right) /\left(\left(\mathrm{HCO}_{3}^{-}+\mathrm{CO}_{3}^{2-}\right)+\left(\mathrm{SO}_{4}^{2-}\right)+\left(\mathrm{Cl}^{-}\right)\right)$ with increasing concentration, as indicated by the chloride, (Eugster \& Jones, 1979) is described by $\left.0.12(\mathrm{Cl})^{0.29}\right)(r=0.97)$ for the more saline low ratio lakes (Lake Basotu which contains freshwater was not included). Thus, chloride enrichment behaves as a regularly increasing function of chloride concentration. Chloride is enriched as carbonate and sulfate ions are lost from solution (Kilham, 1971a; Eugster \& Jones, 1979). Carbonate precipitation (primarily calcite in the Basotu lakes, but a small amount of $\mathrm{Mg}$-calcite (unspecified) was found in sediments of Lake Gidaburk, P. Stoffers, pers. comm.) decreases the total alkalinity.

The correlation between sulfate and alkalinity found for the low ratio lakes results primarily from the interplay between increases in the total alkalinity of a particular lake water (owing to EPA production), calcite precipitation, and magnesium loss. Because the Basotu lakes are supersaturated with respect to calcite (by a factor of ca. 10; WATEQ, Truesdell \& Jones, 1974) most of the EPA produced is probably precipitated as calcite. The correlation between sulfate and alkalinity is not surprising, as Eq. 2 indicates. The final alkalinity is determined by the hydrolysis of alkaline silicates, calcite precipitation, magnesium loss, and the rate at which calcium and magnesium are supplied (from internal and external sources) to the lake.

\section{Calcite precipitation}

Calcite precipitation which is described by

$$
\mathrm{Ca}^{2+}+2 \mathrm{HCO}_{3}^{-} \rightarrow \mathrm{CaCO}_{3}+\mathrm{CO}_{2}+\mathrm{H}_{2} \mathrm{O}
$$

is particularly evident in the lakes strongly affected by sulfide loss. Calcium concentrations at every stage of evaporative concentration are lower in these lakes (Fig. 10). The relationship between calcium and chloride for the four more

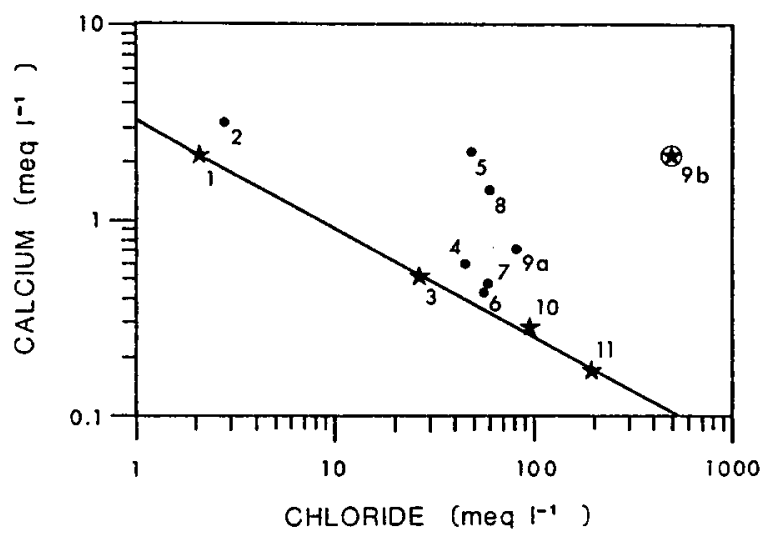

Fig. 10. Plot of calcium versus chloride for the Basotu lakes, Tanzania. The regression line is for four of the five low $\mathrm{SO}_{4}$ : Alk waters (stars). Lake Gidamuniud (monimolimnion, circled star) has an anomalously high calcium concentration. The remaining waters (circles) include Lake Laja and the high $\mathrm{SO}_{4}$ : Alk ratio lakes.

dilute lows ratio lakes is $3.3(\mathrm{Cl})^{-0.56}(r=-1.0$; in meq $1^{-1}$ ). Only Lake Gidamuniud (monimolimnion, 9b) does not fit this relationship (see below). Correlation coefficients for calcium and alkalinity $(r=-0.96)$ and calcium and sulfate $(-0.98)$ are also very high. These data indicate that calcite precipitation induced by EPA production tends to smooth out much of the variability in the relationship between alkalinity and chloride or sulfate potentially caused by vicissitudes in the supply of calcium to the lakes, but other factors are probably also involved.

Magnesium, in addition to calcium, is being lost from solution somewhat more rapidly in the low ratio lakes than in the high ratio lakes. Magnesium concentrations for these waters plot on or below the regression line in Fig. 5B. Müller et al. (1972) have shown that the types of $\mathrm{Ca}-\mathrm{Mg}$ carbonates that precipitate in lakes are largely controlled by the $\mathrm{Mg}$ : Ca ratio of the ambient water. Because the $\mathrm{Mg}: \mathrm{Ca}$ ratios of the Basotu lakes range between 0.48 and 29.4 a variety of $\mathrm{Ca}-\mathrm{Mg}$ carbonates can occur (i.e. low Mg-calcite, high Mg-calcite, aragonite, and sedimentary dolomite). Our sediment samples, which were admittedly limited in number, contained only calcite and $\mathbf{M g}$ calcite (unspecified; P. Stoffers, pers. comm.). Magnesium is also removed during the neo- 
formation of magnesium-rich clays (e.g. various smectites, chlorite, sepiolite, etc.). This sink of magnesium may be of considerable importance in some alkaline, saline lakes (Jones \& Weir, 1983; Yuretich \& Cerling, 1983; Von Damm \& Edmond, 1984).

We know that two of the water samples we obtained were originally anoxic, but became oxidized as a consequence of collection. Lake Gidamur had just turned over when it was visited and the surface water contained ca. $0.4 \mathrm{mM} \mathrm{H}_{2} \mathrm{~S}$. The loss of hydrogen sulfide from the lake surface must have been enormous because the rotten-eggs smell was still detectable more than $5 \mathrm{~km}$ away. The surface of the lake was purple presumably due to a bloom of photosynthetic sulfur bacteria. The reduced monimolimnetic water of lake Gidamuniud also smelled strongly of $\mathrm{H}_{2} \mathrm{~S}$.

Both of these waters are slightly anomalous. The monimolimnetic water of Lake Gidamuniud plots in the regression line of sulfate versus alkalinity for the low ratio lakes (Fig. 9). But, this water has a comparatively high calcium to chloride equivalent ratio $(0.0042)$. The calcium concentration ( $2.03 \mathrm{meq}^{-1}$ ) found is not easy to explain given the data available, but it may be the result of plagioclase dissolution. The surface water of Lake Gidamur is greatly enriched in alkalinity (the Alk : Cl ratio is the highest of all the Basotu lakes: 2.64). This indicates that there probably had not been sufficient time since the lake turned over for calcium inputs to the lake to supply enough calcium to precipitate the EPA generated by the loss of sulfides from solution.

Owing to time constraints, the sample designated Lake Gidamuniud, monimolimnion (Table 2, No. 9b) was the only sample we obtained from an anoxic bottom water. The hydrogen sulfide concentration of this water was very high ( $>9 \mathrm{mM}$ ). Owing to the insolubility of metal sulfides there is an inverse relationship in anoxic waters between the hydrogen sulfide concentration and the concentrations of metals that precipitate as metal sulfides $\left(\mathrm{Fe}^{2+}, \mathrm{Mn}^{2+}, \mathrm{Zn}^{2+}\right.$, etc.: Hutchinson, 1957; Cook, 1984; Nürnberg, 1984). This relationship indicates that ambient metal concentrations were probably extremely low in the monimolimnion of Lake Gidamuniud and that the flux of metal ions into this layer was not sufficient to check gradual increases in the concentration of hydrogen sulfide. Unlike metal sulfides, $\mathrm{H}_{2} \mathrm{~S}$ becomes increasingly soluble as alkalinity increases. Thus, very high concentrations of $\mathrm{H}_{2} \mathrm{~S}$ are sometimes observed in the anaerobic waters of meromictic alkaline, saline lakes (Hutchinson, 1957; Nürnberg, 1984).

\section{Concluding remarks}

Because rapid evolution will occur in any body of water that loses $\mathrm{H}_{2} \mathrm{~S}$ to the atmosphere, this phenomenon is undoubtedly widespread. Lakes in Indonesia, for example, mix only rarely, but when they do fish are sometime killed and the odor of $\mathrm{H}_{2} \mathrm{~S}$ is perceptible in the air (Ruttner, 1931; Hutchinson, 1957, p. 773). Similar events are known to occur frequently at Lake Bosumtwi, Ghana (Whyte in Beadle, 1981). MacIntyre \& Melack (1982) also smelled $\mathrm{H}_{2} \mathrm{~S}$ during a mixing event in Lake Sonachi, Kenya. Mixing events in temperate freshwater lakes also cause $\mathrm{H}_{2} \mathrm{~S}$ to be released to the atmosphere (Folt et al., 1989). The process of rapid evolution, though it was not called that, was studied by King et al. (1974) in a series of laboratory microcosms which initially contained acidic water from a strip mine lake. They recognized the potential importance of rapid evolution in the alkalization of lakes affected by acid mine drainage.

The importance of sulfate reduction, sulfide loss, and the formation of permanent alkalinity in the biogeochemical evolution of lake waters have been recognized previously by Holland \& Christie (1909; Lake Sambhar, India), Anderson (1945; Lake Corangamite, Australia), and Abd-el-Malek \& Risk (1963, Wadi Natrum, Egypt). The biogeochemical sections of these papers are largely qualitative which may explain why they are not better known to limnologists.

Half of the Basotu lakes appear to have evolved largely according to the same slow biogeochemical processes thought to govern the gradual evolution of closed-basin lakes everywhere, but the 
other half have not. They have evolved rapidly at times. The phenomenon of rapid (punctuated) evolution probably occurs in many lakes worldwide and it may explain why plots of sulfate versus alkalinity or chloride often contain considerable scatter that has proven very difficult to interpret.

Hydrogen sulfide is a deadly gas, but we are not aware that the rapid degassing of lakes such as those at Basotu has ever killed anyone. However, until recently, one might have made the same observation for the carbon dioxide that escaped from lakes Nyos and Monoun in Cameroon, West Africa (Kling, 1987).

\section{Acknowledgements}

In Tanzania, this study was made possible by the National Parks System and the Mineral Resources Division. In East Africa valuable field assistance was supplied by the East African Fisheries Research Organization while it was under the direction of J. Okedi. We thank R.M. Baxter, B.F. Jones, S.S. Kilham, R.F. Stallard, and R.E. Stauffer for comments and suggestions. S.S. Kilham, C.M. Hecky, R.E. Hecky, T.J. Harvey, and D.A. Livingstone are thanked for their help and support in the field. This work was supported by NSF grants GB-8328X (to D.A. Livingstone) and OCE81-17377 (from the Oceanography Section to S.S. \& P. Kilham). Final preparation of this paper was supported by the Max-Planck-Institut fur Limnologie, Plön, West Germany and an Alexander Von Humboldt Fellowship (Senior U.S. Award) to the senior author.

\section{References}

Abd-el-Malek, Y. \& S. G. Risk, 1963. Bacterial sulfate reduction and the development of alkalinity. J. appl. Bact. 26: 20-26.

Anderson, V. G., 1945. Some effects of atmospheric evaporation and transpiration on the composition of natural waters in Australia, 3. The waters of interior drainage catchments. J. Proc. Aust. chem. Inst. 12: 60-68.

American Public Health Association, 1965. Standard methods for the examination of water and wastewater, APHA, N.Y., 769 pp.

Arad, A. \& W. H. Morton, 1969. Mineral springs and saline lakes of the western Rift Valley, Uganda. Geochim. cosmochim. Acta 33: 1169-1181.

Beadle, L. C., 1981. The inland waters of tropical Africa. 2nd ed., Longman, London. 475 pp.

Berner, R. A., 1971. Principles of chemical sedimentology. McGraw-Hill, New York.

Carmouze, J.-P., 1983. Hydrochemical regulation of the lake. In J.-P. Carmouze, J.-R. Durand \& C. Lévêque (eds.), Lake Chad, Ecology and Productivity of Shallow Tropical Ecosystem. Dr. W. Junk, The Hague: 95-123.

Cerling, T. E., 1979. Paleochemistry of Plio-Pleistocene Lake Turkana, Kenya. Paleogeogr. Paleoclimatol. Paleoecol. 27: 247-285.

Cook, R. B., 1984. Distributions of ferrous iron and sulfide in an anoxic hypolimnion. Can. J. Fish. aquat. Sci. 41: 286-293.

Dawson, J. B., 1964. Carbonatitic volcanic ashes in Northern Tanganyika. Bull. volcan. 27: 81-91.

Downie, C. \& P. Wilkinson, 1962. The explosion craters of Basotu, Tanganyika Territory. Bull. volcan. 14: 389-420.

Drever, J. I., 1988. The geochemistry of natural waters. 2nd ed. Prentice-Hall, Englewood Cliffs. 437 pp.

Dunnette, D. I., D. P. Chynoweth \& K. H. Mancy, 1985. The sources of hydrogen sulfide in anoxic sediment. Wat. Res. 19: 875-884.

Eades, N. W. \& W. H. Reeve, 1938. Explanation of the geology of degree sheet No. 29 (Singida). Bull. geol. Div. Tanganyika Dep. Lands Mines 11: 5-59.

Eugster, H. P., 1970. Chemistry and origin of brines of Lake Magadi, Kenya. Spec. Pap. mineralog. Soc. Am. 3: 215-235.

Eugster, H. P. \& B. F. Jones, 1979. Behavior of major solutes during closed-basin brine evolution. Am. J. Sci. 279: 609-631.

Eugster, H. P. \& G. Maglione, 1979. Brines and evaporites of the Lake Chad basin, Africa. Geochim. cosmochim. Acta 43: 973-981.

Folt, C. L., M. J. Wevers, M. P. Yoder-Williams \& R. P. Howmiller, 1989. Field study comparing growth and viability of a population of phototrophic bacteria. Appl. envir. Microbiol. 55: 78-85.

Gasse, F., J. F. Talling \& P. Kilham, 1983. Diatom assemblages in East Africa: classification, distribution, and ecology. Revue Hydrobiol. trop. 16: 3-34.

Garrels, R. M. \& F. T. Mackenzie, 1967. Origin of the chemical composition of some springs and lakes. In Equilibrium Concepts in Natural Water Systems. Adv. Chem. Ser. 67: 222-242.

Goldhaber, M. B. \& I. R. Kaplan, 1974. The sulfur cycle. In E. D. Goldberg (ed.), The Sea, 5. Interscience, N.Y.: 569-655.

Hardie, L. A. \& H. P. Eugster, 1970. The evolution of closedbasin brines. Spec. Pap. mineralog. Soc. Am. 3: 273-290. 
Hecky, R. E. \& P. Kilham, 1973. Diatoms in alkaline, saline lakes: Ecology and geochemical implications. Limnol. Oceanogr. 18: 53-71.

Heinrich, E. W., 1966. The geology of carbonatites. Rand McNally \& Co., Chicago.

Holland, T. H. \& W. A. K. Christie, 1909. The origin of the salt deposits of Rajputana. Rec. geol. Surv. India 38: 154-186.

Hutchinson, G. E., 1957. A treatise on limnology, 1. J. Wiley \& Sons, N.Y., 1015 pp.

Jones, B. F., H. P. Eugster \& S. L. Rettig, 1977. Hydrogeochemistry of the Lake Magadi basin, Kenya. Geochim. cosmochim. Acta 41: 53-72.

Jones, B. F. \& A. H. Weir, 1983. Clay minerals of Lake Abert, an alkaline, saline lake. Clays Clay Mineral. 31: 161-172.

Kilham, P., 1971a. The geochemical evolution of closed basin lakes. Abstrs. Progms. geol. Soc. Am. 3(7): 770-772.

Kilham, P., 1971b. Biogeochemistry of African lakes and rivers. Ph.D. thesis, Duke Univ., Durham (N.C.), 199 pp.

Kilham, P., 1984. Sulfate in African inland waters: sulfate to chloride ratios. Verh. int. Ver. Limnol. 22: 296-302.

Kilham, P. \& R. E. Hecky, 1973. Fluoride: Geochemical and ecological significance in East African waters and sediments. Limnol. Oceanogr. 18: 932-945.

King, D. L., J. J. Simmler, C. S. Decker \& C. W. Ogg, 1974. Acid strip mine lake recovery. J. Wat. Pollut. Cont. Fed. 46: 2301-2316.

Kling, G. W., 1987. Seasonal mixing and catastrophic degassing in tropical lakes, Cameroon, West Africa. Science 237: 1022-1024.

MacIntyre, S. \& J. M. Melack, 1982. Meromixis in an equatorial African soda lake. Limnol. Oceanogr. 27: 595-609.

Mackereth, F. J. H., 1963. Some methods of water analysis for limnologists. Scient. Publ. Freshwat. biol. Ass. 21. 71 p.

Müller, G., G. Irion \& U. Förstner, 1972. Formation and diagenesis of inorganic Ca-Mg carbonates in the lacustrine environment. Naturwissenschaften 59: 158-164.
Nürnberg, G., 1984. Iron and hydrogen sulfide interference in the analysis of soluble reactive phosphorus in anoxic waters. Wat. Res. 18: 369-377.

Pappe, A. \& H. D. Richmond, 1890. A Central African salt lake. J. Soc. chem. Ind. Lond. 9: 734.

Perkin-Elmer, 1964. Analytical methods for atomic absorption spectrophotometry. Perkin-Elmer, Norwalk. Looseleaf, unpaginated.

Prosser, M. V., R. B. Wood \& R. M. Baxter, 1968. the Bishoftu crater lakes: A bathymetric and chemical study. Arch. Hydrobiol. 65: 309-324.

Rodhe, H. \& H. Virji, 1976. Trends and periodicities in East African rainfall data. Mon. Weath. Rev. U.S. Dep. Agric. 104: 307-315.

Ruttner, F., 1931. Hydrographische und hydrochemische Beobachtungen auf Java, Sumatra und Bali. Arch. Hydrobiol. Suppl. 8: 197-454.

Singer, A. \& P. Stoffers, 1980. Clay mineral diagenesis in two East African lake sediments. Clay Mineral. 15: 291-307.

Stanley, H. M., 1890. In darkest Africa, 2. Charles Scribner's Sons, N.Y., 540 pp.

Talling, J. F. \& I. B. Talling, 1965. The chemical composition of African lake waters. Int. Revue ges. Hydrobiol. 50: 421-463.

Truesdell, A. H. \& B. F. Jones, 1974. WATEQ, a computer program for calculating chemical equilibria of natural waters. J. Res. U.S. geol. Serv. 2: 233-248.

Von Damm, K. L. \& J. M. Edmond, 1984. Reverse weathering in the closed-basin lakes of the Ethiopian Rift and in Lake Turkana (Kenya). Am. J. Sci. 284: 835-862.

Wood, R. B. \& J. F. Talling, 1988. Chemical and algal relationships in a salinity series of Ethiopian inland waters. Hydrobiologia 158: 29-67.

Yuretich, R. G. \& T. E. Cerling, 1983. Hydrogeochemistry of Lake Turkana, Kenya: Mass balance and mineral reactions in an alkaline lake. Geochim. cosmochim. Acta 47: 1099-1109. 